\title{
Teaching Innovation in the Development of Professional Practices: Use of the Collaborative Blog
}

\author{
Carmen Corujo-Vélez ${ }^{1}$ (D), Raquel Barragán-Sánchez ${ }^{2, *} \mathbb{D}$, Carlos Hervás-Gómez ${ }^{2}$ (D) \\ and Antonio Palacios-Rodríguez ${ }^{2}$ (D) \\ 1 Department of Research and Diagnostic Methods in Education, University of Seville, 41013 Seville, Spain; \\ mcorujo@us.es \\ 2 Department of Teaching and Educational Organization, University of Seville, 41013 Seville, Spain; \\ hervas@us.es (C.H.-G.); aprodriguez@us.es (A.P.-R.) \\ * Correspondence: rbarragan@us.es
}

Citation: Corujo-Vélez, C.;

Barragán-Sánchez, R.; Hervás-Gómez,

C.; Palacios-Rodríguez, A. Teaching Innovation in the Development of Professional Practices: Use of the Collaborative Blog. Educ. Sci. 2021, 11, 390. https://doi.org/10.3390/ educsci11080390

Academic Editor: Neil Gordon

Received: 22 June 2021

Accepted: 26 July 2021

Published: 29 July 2021

Publisher's Note: MDPI stays neutral with regard to jurisdictional claims in published maps and institutional affiliations.

Copyright: (C) 2021 by the authors Licensee MDPI, Basel, Switzerland. This article is an open access article distributed under the terms and conditions of the Creative Commons Attribution (CC BY) license (https:// creativecommons.org/licenses/by/ $4.0 /)$
Abstract: The development of professional practices during the university stage is a fundamental factor for quality skills development. For many students, it is the first real experience in a professional context, so continuous monitoring by teachers is necessary. This article presents an innovative proposal to develop the follow-up of the professional practices of the degree in Primary Education, and two Masters' in Psychopedagogy and Special Educational Needs using a learning management system (LMS) (Blackboard). The experience was developed by a team of teachers from the departments of Didactics and Educational Organization and Research Methods and Educational Diagnosis of the University of Seville (Spain). The aspects to be studied are the development of communication, reflection, and collaborative learning processes during the internship period. After an explicit agreement, 24 students (10 from the course "Professional Practices I" in undergraduate students; and the others from the Master's) committed to periodically using the blog designed ad hoc for this experience. A content analysis of the speeches posted on the blog was carried out, examining the changes, the advantages, and the disadvantages that this model entailed. It allowed observing similarities and differences between both groups of students. As the main conclusion, there were some differences between the two groups of students, regarding the number, type, and contents of interventions; there were no differences in the assessment of the methodology, all the students thought that it was a very positive assessment of the experience for generating information exchange networks among colleagues and teachers. Finally, the relevance of constant monitoring of the academic tutor was highlighted.

Keywords: technology-enhanced learning; computer-mediated learning; innovation; external practices

\section{Introduction}

The integration of information and communication technologies (ICTs) in higher education and its impact on pedagogical methods is one of the emerging themes in international research on ICT [1]. At the same time, [2] ICTs facilitate a certain way of working, allow other training scenarios and a new system of practical learning in the training of future professionals who will join the world of work from university classrooms.

Training through external practices developed in professional contexts (practices) leads to a training activity at the university as a period of curricular training physically outside the institution $[3,4]$. During the professional practices, ICT not only contributes to the digital literacy of future teachers, but also favors a more efficient development of work during the process of immersion in the professional context [5]. For this reason, they become an essential vehicle for communication in the participation of practical experiences from a collaborative point of view [6]. In addition, they are shown as resources that offer instrumental, relational, documentary, institutional, and didactic support in the observation, collaboration, and intervention phases [7]. 
The professional practices become a privileged space and an ideal opportunity expressly designed for students to investigate, reflect, and build their practical thinking from the interactions that can be established between the theoretical approaches and the experiences that are lived in the different professional contexts [8]. The didactic integration of collaborative work tools during the internship process [9] generates important repercussions to help in both the selection of activities or cognitive challenges and the stimulation of the intrinsic motivation of the students [10], as well as in the incorporation and development of collaborative work strategies [11].

In the educational experience presented, future teachers experienced the experiences in their practice centers feeling at all times accompanied and valued by their own classmates $[9,12]$. The objective was to achieve the activation of professional action competencies. The proposed methodology was constructive and based on learning projects that are incorporated into the learning ecosystem [13]. On the other hand, it was also based on the socio-cognitive scaffolding. This facilitates students learning collaboratively and its effectiveness in university contexts is demonstrated in numerous studies [14-18]. In this experience, the training process was reinforced with a blog so that, in addition to sharing their dilemmas and feelings [19], students also carried out interdisciplinary work [20] with the help of academic tutors specialized in different academic disciplines [21], establishing a cooperation between centers and the faculty [22]. In different universities, the digital portfolio has been used as a means to facilitate the connection between the teaching staff and the student body $[2,23,24]$. It has also been used to assess the potential of this resource to promote dialogic communication between students and teachers [25], in addition to facilitating the supervision of practices. This question is also supported by [26], since it allows, in addition to monitoring, to redirect unwanted situations in practice centers from a distance. On the other hand, students also find advantages in its use since it allows them to integrate knowledge and reflect on their learning process [27]. However, in the research, a different model is proposed through a discussion forum. This allows, in addition to the reflection and construction of individual knowledge, the joint reflection and construction of all the students in practices, mediated by the teachers. It is more similar to the blog format, which allows to open and expose, if desired, the didactic interaction that teacher and student have maintained in classic spaces such as tutoring [28]. In the university where this research is carried out, experiments in this sense have also been carried out; authors such as $[29,30]$ have opted for the blog format to monitor and evaluate internship students, progressively increasing the use of technologies for tutoring external internships, but focusing mainly on the practices of different degrees. Unlike these investigations, this study includes the use of the blog and its analysis for the professional practices of different Masters' Degree of specialization in the educational field. This implies a different form of use with respect to undergraduate students.

To understand the context of the study, the organization of professional practices in the curricula of the Faculty of Education of a Spanish university is briefly described. The practical credits are organized differently in the Bachelor's and Master's degrees. While in the Grade of Primary Education (3rd year), Professional Practices I has a duration of $300 \mathrm{~h}$, is carried out in the 2nd semester, and is compulsory. In the Master's, Professional Practices has a duration of $60 \mathrm{~h}$ and is carried out in the middle of the training period. It is also compulsory in the University Master's degree in special educational needs and attention to diversity at school, but optional in the Master's degree in psychopedagogy. The aims or objectives of the professional practices at a general level are to:

1. Contribute to the comprehensive training of students by completing their theoretical and practical learning.

2. Facilitate knowledge of the work methodology appropriate to the professional reality in which the students will have to operate, contrasting and applying the knowledge acquired.

3. Encourage the development of technical, methodological, personal, and participatory skills. 
4. Obtain practical experience that facilitates insertion into the job market and improves your future employability.

5. Favor the values of innovation, creativity, and entrepreneurship.

To develop these objectives, it is understood that professional practices are a set of actions that make up the daily work of teachers, exercised through subjective interrelationships with students, based on certain training purposes [31-34]; a new methodology is articulated for the accompaniment of students in their internship period.

Previous experience has shown that although the meetings held on this reflective need have been insisted on, it has not been enough. In fact, waiting until the end to assess this period usually left students unhappy with the results. In most cases, they focused on writing in a descriptive way what happened in each school day without critical contributions, proposals for improvement, or theoretical reflections. For this reason, an evaluation was chosen in the interactive phase [32,35], since it really facilitates learning.

In addition, personal motivation as innovative teachers, whose objective is the inclusion of technologies in the training process [36], encouraged making this proposal.

In the first meeting, students were informed of the possibility of keeping track of the practices, in addition to the traditional way (with meetings and emails), through the "Coursesites" platform, through a discussion forum. After receiving consent, a short user guide was provided on the platform with simple instructions. As necessary requirements to opt for this internship-monitoring model, it was proposed that students make at least one entry weekly. This should refer to the topic or question proposed. It was also encouraged to answer any questions that may arise among students.

In the degree in primary education, the debates were structured around different weekly themes. They set an objective and a brief description of what they should include. Next, Table 1 shows the timing and the proposed objectives.

Table 1. Distribution of fora in the degree in primary education.

\begin{tabular}{cc}
\hline Timing & Objectives \\
\hline First week from 4 to 10 March 2019 & Describe the center context. \\
Second week from 11 to 17 March 2019 & Describe the classroom context. \\
Third week from 18 to 24 March 2019 & Identify characteristics of the students. \\
Fourth week from 25 to 31 March 2019 & Identify methodologies used by teachers. \\
Fifth week from 1 to 7 April 2019 & Identify strategies of attention to diversity used by teachers. \\
Sixth week from 8 to 14 April 2019 & Identify evaluation methods/instruments/types. \\
Seventh week from 22 to 28 April 2019 & Prepare didactic proposal. \\
Eighth week from 29 April to 5 May 2019 & Develop didactic proposal. \\
Ninth week from 6 to 12 May 2019 & Prepare didactic proposal. \\
Tenth week from 13 to 19 May 2019 & Develop didactic proposal. \\
Eleventh week from 20 to 26 May 2019 & Evaluate the practices carried out. \\
\hline
\end{tabular}

Source: made by the authors.

These objectives are linked to those of the practice report that they had to carry out as an assessment document for the practices.

In the case of the Master's students, having more experience and a shorter duration of their internships, only an open forum was established and the instructions given to the students were to write observations about the context, the professionals of the centers, the climate of the centers, the activities carried out, doubts, reflections, proposals for improvement, etc.

The teachers' interventions are not specified here because the objectives of the article are focused on identifying the vision of the students. However, the teaching staff participated by initiating discussions, asking questions and clarifying certain topics, resolving doubts, and motivating the students when they expressed difficulties in their practice centers or explaining what was done in them. It also included specific information on certain theoretical topics to facilitate reflection between the theory and the practice of the students. 
The proposed research objectives were:

1. Identify the level of participation according to the degrees (O1).

2. Distinguish the type of participation of the students according to the degrees $(\mathrm{O} 2)$.

3. Explore the content of the students' contributions to the fora (O3).

4. Know the students' assessment of the follow-up of the professional practices with this methodology (O4).

\section{Methods}

To carry out this research, a mixed methodology was developed, which combined the study of quantitative variables (participation analysis, averages of publications, and written words made by students in the fora) and qualitative, through documentary analysis (Figure 1).

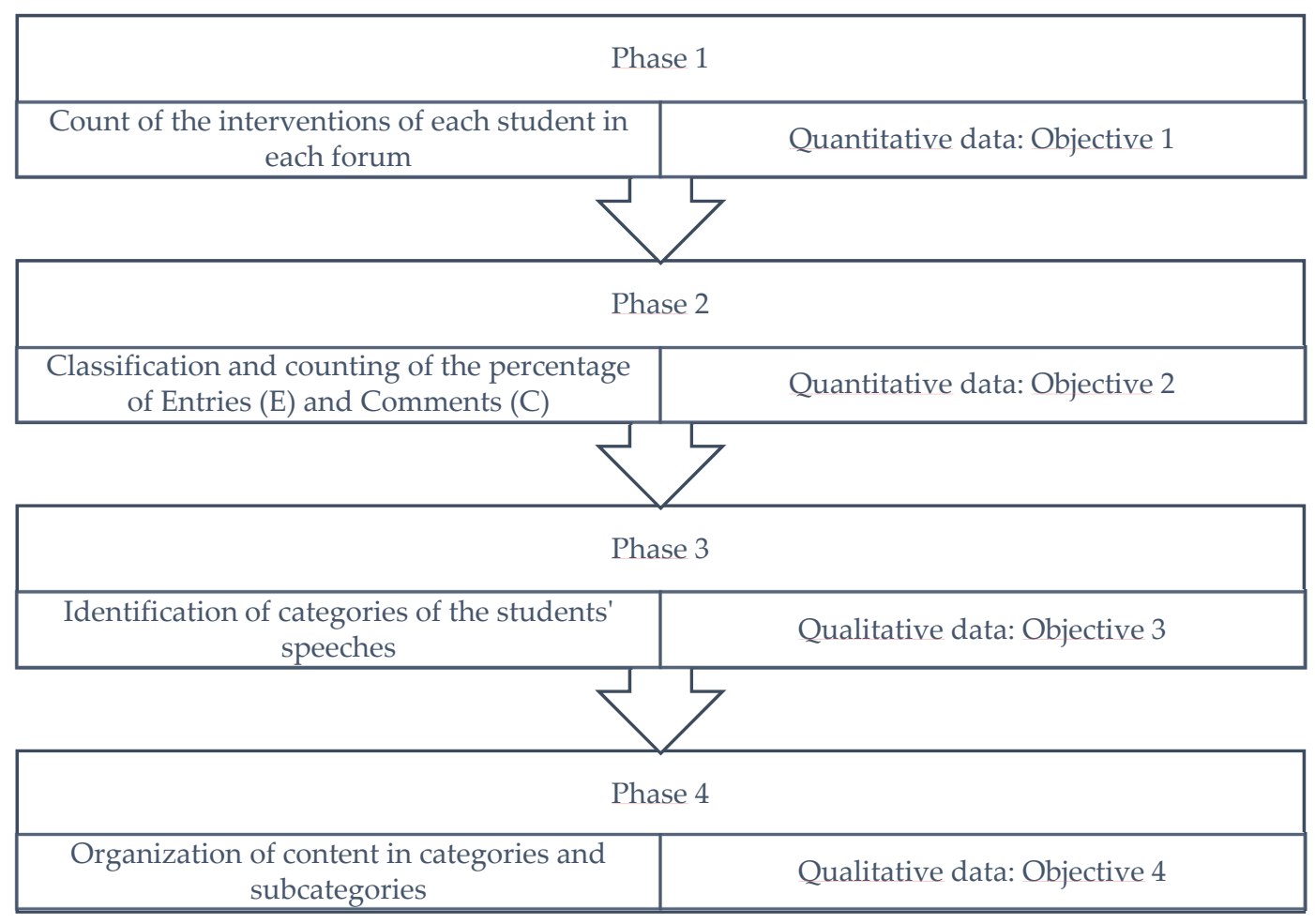

Figure 1. Data collection and analysis procedure in relation to the objectives of the study.

The Atlas-ti program was used to establish the categories, by agreement between researchers, of the content of the fora. The sampling method was incidental, since it dealt with the students (sample) available in the time or research period that was assigned to the teaching staff. The selection of students was carried out by the faculty, so that each teacher was assigned a variable number of students, regardless of the internship center where they were assigned. The sample of 24 students was obtained over four courses in different degrees and postgraduate degrees. Specifically, it had 10 third-year students of the degree in primary education (2018-2019 academic year), 5 students of the Master's degree in psychopedagogy (2019-2020 academic year), and 4 students of the Master's degree in educational needs and attention to diversity in school (ENADS, hereinafter) and 5 of the Master's in psychopedagogy, both in the 2020-2021 academic year. They were all women, except for one ENADS Master's student.

The centers where they carried out the internships are public, concerted nature, and private: the public centers were 10 early childhood and primary education schools, 2 secondary education institutes, and 2 educational guidance teams; the concerted nature centers were 2 schools of early childhood, primary, and secondary education; and the private cen- 
ters were 4 non-profit educational associations (psychosanitary or socio-educational), 1 educational cabinet, and 2 equestrian therapeutic rehabilitation centers.

The procedure followed to identify the quantitative data consisted of carrying out a manual count of the data provided by the platform used, taking averages of the interventions of each student in each of the fora. In the case of the Bachelor's students, each week a new topic and objective was introduced, so in reality, 11 fora were developed. To facilitate the comparison with the data from the Master's students, the average of all the fora was calculated.

For qualitative analysis, an inductive and emergent process was followed in the creation and application of the categories of discourse analysis. The constant comparison and cross-checking method was used. Cohen's kappa coefficient for coding reliability yielded an index of 0.89 . This implies an excellent coding reliability index [36,37]. The kappa index $(\mathrm{K})$ is used to check the concordance of the measurement instrument category systems whose result is categorical ( 2 or more categories). It represents the proportion of matches observed beyond chance. The established categories can be seen in Table 2 .

Table 2. System of categories of the contributions to the fora.

\begin{tabular}{|c|c|c|c|c|}
\hline \multicolumn{5}{|c|}{ Contributions to Fora (Categories) } \\
\hline $\begin{array}{l}\text { 1-Descriptions: } \\
\text { they explain the } \\
\text { physical, social, } \\
\text { and functional } \\
\text { characteristics of } \\
\text { the practice } \\
\text { centers and the } \\
\text { geographical } \\
\text { area where they } \\
\text { are located. }\end{array}$ & $\begin{array}{l}\text { 2-Feelings: } \\
\text { evolution and } \\
\text { changes in } \\
\text { emotions and } \\
\text { feelings } \\
\text { experienced } \\
\text { throughout the } \\
\text { internship period. }\end{array}$ & $\begin{array}{l}\text { 3-Reflections: } \\
\text { relationships } \\
\text { between } \\
\text { theories and } \\
\text { practices, as } \\
\text { well as personal } \\
\text { ones in } \\
\text { different areas } \\
\text { of practice. }\end{array}$ & $\begin{array}{l}\text { 4-Supports: } \\
\text { types of help } \\
\text { and } \\
\text { collaboration } \\
\text { students } \\
\text { provided each } \\
\text { other during the } \\
\text { learning process. }\end{array}$ & $\begin{array}{l}\text { 5-Doubts and } \\
\text { answers: } \\
\text { messages from } \\
\text { students in } \\
\text { which doubts or } \\
\text { queries are } \\
\text { raised and } \\
\text { answers are } \\
\text { provided for } \\
\text { their resolution. }\end{array}$ \\
\hline
\end{tabular}

Source: Made by the authors.

\section{Results}

The results obtained based on the proposed objectives are described below.

\subsection{Participation According to the Different Degrees}

To identify the level of participation according to the degrees (O1), it can be verified (Table 3) that, in all the courses, all the students participated in the debates.

Table 3. Average participation in fora by specialty.

\begin{tabular}{cccccc}
\hline Specialty/Course & $\begin{array}{c}\text { Active } \\
\text { Students }\end{array}$ & $\begin{array}{c}\text { No. of } \\
\text { Debates }\end{array}$ & $\begin{array}{c}\text { Average Posts Per } \\
\text { Student }\end{array}$ & $\begin{array}{c}\text { Average Word } \\
\text { Count }\end{array}$ & $\begin{array}{c}\text { Average Debate } \\
\text { Rating }\end{array}$ \\
\hline $\begin{array}{c}\text { Primary Education (2018-2019) } \\
\text { Master's in Psychopedagogy } \\
\quad \text { (2019-2020) }\end{array}$ & 10 & 11 & 1.26 & 510.29 & $100 \%$ \\
$\begin{array}{c}\text { Master's in ENADS } \\
\text { (2020-2021) }\end{array}$ & 5 & 1 & 2.4 & 385.25 & $100 \%$ \\
$\begin{array}{c}\text { Master's in Psychopedagogy } \\
\text { (2020-2021) }\end{array}$ & 4 & 1 & 14.75 & 728.7 & $100 \%$ \\
\hline
\end{tabular}

Source: made by the authors. Average posts per student is the percentage of interventions in the forum of each student; average word count is the total percentage of words written by each student; and average debate rating indicates the percentage of students who participated in the debates.

The most participatory students in terms of number of publications were those of the Master's in ENADS, followed by those of the Master's in Psychopedagogy of the 2020-2021 academic year, and those who participated less were those of the degree in primary education. 
With reference to the Masters', differences were also observed between them, the contributions of the students of the Master's in psychopedagogy being very different in the two courses (2.4 publications on average in the 2019-2020 academic year and 8 in the next). This difference has a clear explanation and it is the interruption of the practices due to the lockdown caused by COVID-19, which forced the students to end the practices abruptly, preventing the collection of new data to contribute to the forum. Subsequent communications were made by email.

\subsection{Type of Participation According to the Different Degrees}

Next, Table 4 shows the type of student participation according to the degrees $(\mathrm{O} 2)$, grouped into two blocks. On the one hand, the entries (E) were counted, which were defined as the interventions initiated by each student in which they responded to the content of the debate or to the question posed by the teacher; on the other hand, comments (C) were counted, which included questions and/or answers to the entries made by other colleagues. This made it possible to identify the type of interaction that occurred in the different fora, responding to the second objective.

Table 4. Type of participation depending on the degree.

\begin{tabular}{|c|c|c|c|c|c|c|c|c|}
\hline \multirow{2}{*}{$\begin{array}{c}\text { Specialty/ } \\
\text { Course }\end{array}$} & \multicolumn{2}{|c|}{$\begin{array}{c}\text { Education } \\
\text { Primary } \\
(2018-2019)\end{array}$} & \multicolumn{2}{|c|}{$\begin{array}{c}\text { Master's Degree } \\
\text { Psychopedagogy } \\
\text { (2019-2020) }\end{array}$} & \multicolumn{2}{|c|}{$\begin{array}{c}\text { Master's Degree } \\
\text { ENADS } \\
(2020-2021)\end{array}$} & \multicolumn{2}{|c|}{$\begin{array}{c}\text { Master's Degree } \\
\text { Psychopedagogy } \\
\quad(2020-2021)\end{array}$} \\
\hline & $\mathrm{E}$ & $\mathrm{C}$ & $\mathrm{E}$ & $\mathrm{C}$ & $\mathrm{E}$ & $\mathrm{C}$ & $\mathrm{E}$ & $\mathrm{C}$ \\
\hline 1 & 9 & 5 & 1 & 3 & 3 & 17 & 7 & 20 \\
\hline 2 & 10 & 3 & 1 & 2 & 4 & 14 & 6 & 9 \\
\hline 3 & 11 & 0 & 1 & 1 & 4 & 17 & 7 & 7 \\
\hline 4 & 10 & 1 & 1 & 1 & 4 & 13 & 5 & 7 \\
\hline 5 & 11 & 2 & 1 & 0 & & & 6 & 5 \\
\hline 6 & 9 & 7 & & & & & & \\
\hline 7 & 10 & 1 & & & & & & \\
\hline 8 & 9 & 3 & & & & & & \\
\hline 9 & 11 & 1 & & & & & & \\
\hline 10 & 11 & 0 & & & & & & \\
\hline \multirow{3}{*}{$\begin{array}{l}\text { TOTALS } \\
\text { GROUPED } \\
\text { TOTALS }\end{array}$} & 101 & 23 & 5 & 7 & 15 & 61 & 31 & 48 \\
\hline & Grade & & $\begin{array}{c}\text { Master's } \\
\text { Degree }\end{array}$ & & & & & \\
\hline & 101 & 23 & 51 & 100 & & & & \\
\hline
\end{tabular}

Source: made by the authors. Legend: $\mathrm{E}=$ entries, $\mathrm{C}=$ comments.

Taking into account the number of interactions, it was observed that the students of the Master's in ENADS responded the most and questioned and encouraged their classmates, with 61 comments, followed by students of the Master's in psychopedagogy (2020-2021 academic year) with 48 comments. On the other hand, those of the Master's in psychopedagogy of the 2019-2020 academic year, despite their low participation, maintained a greater balance between entries and comments.

In the case of primary education students, they practically limited themselves to writing about the proposed topics, albeit abundantly, with 101 entries, but they interacted very little with each other (23 comments), being reinforced, challenged, or fundamentally questioned by the teaching staff. Of these comments, none were made between students, but they were answers to questions or clarifications proposed by the teaching staff.

\subsection{Analysis of the Content Provided in the Fora}

Before responding to Objective 3 , to identify the contributions of each student, respecting their identity, the following abbreviations are used: 
$\mathrm{EP}=$ primary education

$\mathrm{MP}=$ Master's degree psychopedagogy (MP21 is the course)

$\mathrm{MN}=$ Master's degree ENADS

AA $=$ Student (woman)

$\mathrm{AO}=$ Student (man)

and the number that follows each of them corresponds to those of each student, which appears in Table 4. To answer O3, we began from the content analysis and the categories described (Table 2), identifying if there were differences between the groups of students.

Category 1-Descriptions:

In the descriptions, those referring to the practice centers were observed, which included physical characteristics, decorative aspects, and the use of the spaces, as well as the number of professionals in the spaces and their functions. In general, they included many details and the total number of students adding photos and plans to these descriptions, thus facilitating the approach to their reality: "The main building is in the shape of a $U$ and contains the children's facilities to the north, one floor; the primary facilities to the south, with two floors; and the offices (secretariat, management, teachers' room, Association of Mothers and Fathers of Students (A.M.P.A.), etc.) to the west, which unite infant and primary school and occupy one floor, also connected to other independent facilities "(EPPAA2); "The center is made up of a staff of 39 teachers; dividing seven teachers in Early Childhood Education and nineteen teachers in Primary Education, in relation to the specialties we find a support teacher for children, two teachers of Religion; a Special Education instructor, a primary school support teacher, a music teacher, two Physical Education teacher, three English teachers, two French teachers, an Audition and Language teacher, two pedagogues (Therapeutic Pedagogy). In addition, the center has a Counselor from the Educational Guidance Team (E.O.E.) who attends once a week" (EPAA3).

They also included data on the area and its socio-economic and cultural characteristics: "Its location is in the northern part of the town in a middle-class neighborhood, which is why most of its students come from stable family backgrounds, with an average family economy predominating; speaking of the family, it has a great participation in the center. Approximately $2 \%$ of the students come from immigrant families, most of them of Maghreb origin. Most families define themselves with a Christian religious ideology" (EPAA10); resorting, in many cases to Internet data to provide maps and geographic references: "It is located at an altitude of $76 \mathrm{~m}$ above sea level, and $45 \mathrm{~km}$ from the capital of the province, Seville. Its geographical coordinates are $36^{\circ} 59^{\prime} \mathrm{N}, 5^{\circ} 56^{\prime} \mathrm{W}$ “(EPPA4).

The students of the degree in primary education made more precise and objective descriptions than those of the Masters' degrees, who gave more general descriptions: “... located in Seville, specifically in the La Rosaleda neighborhood whose socio-economic level is medium" (MP21AA2), or focused on aspects that caught their attention; that is, they were more selective in their descriptions, and also included opinions: "In this way, taking into account the size of the center, more than a thousand students, it is not surprising that the orientation team consists of four professionals"(MPAA1); "It is quite small, since it consists of one line per course and is very familiar, so families are involved in the education of their children and can access and participate with the center whenever they wish" (MPAA4).

Category 2-Feelings:

The feelings changed throughout the internship period, both in undergraduate and Master's students. At the beginning, they were expectant, nervous, and with doubts regarding their functions in the internship centers: "at the beginning as in everything I was a little scared, but from the first day I have been welcomed as one more by both the students themselves and the teachers at the center (EPAA3); "I have to admit that the range of emotions that I experienced was quite wide, I was super excited since I missed working, but I also had a bit of anxiety about all the new things that I am facing, since I have always worked as an educator in childish or supportive ... in fact I felt very comfortable right away "(MP21AA3); “ ... The first days I felt a bit lost in high school, I could not quite understand what the guidance counselor's functions were and what she could contribute, and the 
truth is that I was overwhelmed by thinking that I was going to have that feeling until the internship was over. (MP21AA4); "You can imagine the level of stress and frustration that I had the first days. I felt useless and very clumsy since everything I did was not sure that it was done well and I constantly had to ask him for help" (MP21AA4). Most reflected this type of feeling except for one student who maintained positive previous expectations: "From the moment I arrived I had very good feelings because they treated me like one more..." (MP21AA1).

Although these sensations appeared only in the first week, or even in the first days, they improved rapidly because they found meaning in it and they clarified their functions in the centers: "For now, my feelings in the center are positive ... it is giving me the possibility to experience how problems are approached from different perspectives. Therefore, I see in these practices a great opportunity to learn everything I can" (MPAA1); "In general, I am really enjoying the experience because I see the reality of different centers and I can observe the different needs that students may present, how to determine them and the resources that are offered to them for adequate school development" (MPAA2); "I really liked being able to learn about High Abilities, mainly because of the willingness that my tutor has when teaching me, I have felt very welcome in this center, which has different support materials, the which have been made available to me" (MPAA3); "I am quite happy. In general I am very happy with the experience I am having" (MPAA5); "I also commented that after these first weeks of class I feel better than I expected" (EPAA3); “ .. I am still quite happy and every day I am more eager to learn new things" (MPAA4); "In general I am very happy with the course of the internships and I think it is being a unique learning opportunity" (MPAA1).

Depending on the results obtained and the treatment received, there were emotional ups and downs in the students, and mixed feelings. For example, students valued that they trusted them, asked for their opinion, or involved them in specific tasks: "in this center they are giving me all possible facilities and they are taking my opinion into account at all times, in addition to taking me as one more and fully trusting in my abilities, something that does not always happen ... , I am very excited that two cases have been entrusted to me "(MPAA4); "Regarding the climate with my tutor, I feel very welcome and integrated, we maintain a relationship of respect and cordiality, and we support each other in the teaching process" (EPAA10); "I have been especially excited that my tutor treats me like another teacher and counts on me for everything. On one of the occasions, she told me: How well it works with your help! With this comment I felt quite grateful" (EPAA8). In this category, we did not find differences between Bachelor's and Master's students.

We exemplify the opposite case with these entries " . . but today I had a somewhat stressful morning and I got a bit frustrated ... until the moment when he pulled my hair; I became very angry and told him not to do that again and not to talk to me anymore until the return. When commenting to the coordinator, one of the association's workers, she did not do or comment anything about it, she only said that he was a complicated child due to his circumstances; I felt very frustrated and speaking with her I commented that I thought that this child was allowed a lot because of her 'circumstances' and that it did not help him. But she continued without saying anything about it" (MP21AA1); "... which has sometimes frustrated me since some content was not mastered" (MPS21AA2). Feelings related to COVID-19 were also collected: "It is very sad to observe the differences with respect to normality, when you could physically and calmly access the center, but anyway I notice how the I.E.S. he is doing the impossible" (MP21AA3).

Category 3-Reflections:

In the theoretical reflections, concepts from the didactic field were collected, such as traditional methodology, problem-based learning (PBL), flipped classroom, ABN method in mathematics; types of evaluation; strategies for attention to diversity (flexible groupings, curricular adaptations, early stimulation), names of tests and tests (Merrill-Palmer-R (MPR) Development Scales, K-BIT, and ABAS-II, Piers self-concept test-Harris, ... ), and more psychological terms such as effectance, homnonymia, intrinsic motivation, and theory of 
facial feedback emotion, among others. The fundamental difference observed between Bachelor's and Master's students was that the former did not relate the contents to specific subjects of the degree, while the latter made explicit reference to the subjects where they learned these theoretical contents. As an example of this, we show the following quotes: "I thought about making a behavior contract with N., one of the techniques that I have learned in the course of Conduct Disorders in this Master. The purpose of applying it has always been to motivate him and encourage his desire to learn "(MNAO3); "The strategy used was related to a subject of the master's degree, specifically with processes in educational guidance and psycho-pedagogical counseling, where in block 1 theoretical foundations of the Golden5 program, we could see that we have to apply attributions of unintentionality and if we use this strategy and behave as they do, we do not expect more benefits, so we have to try to do things differently, with "try" possibilities" (MPAA1).

With regard to personal reflections, it was observed that the undergraduate students did not begin to make personal criticisms or comments until the fourth week in the centers, and when they did, they specified that they were their own contributions: "Personally, it seems to me a very successful application and that perfectly fulfills the desired function quickly and easily" (EPAA4). The most forceful reflections referred to the methodology: "from my point of view, the teams were not well balanced, which resulted in various conflicts in some, while others were magnificent" (EPAA6) and to the evaluation: "I think this methodology is very successful for them to develop the ability to seek information and investigate, but above all for them to learn to speak and express themselves in public. Creativity is also encouraged when making the model, so it is a project that, although it is Natural or Social, has a transversal nature with other subjects. However, the evaluation of the contents is still by means of an exam" (EPAA4); "In short, the evaluation methods used are quite limited, the average of the written exams being the majority of the student's grade, with the completion of activities and notebook review a small percentage of the grade depending on the subject and being able to raise the grade to the student taking into account the attitude "(EPAA2); "I disagree with the official evaluation, because finally what teachers usually do is the average of the exams and according to some items of each student, they raise the grade a little or not" (EPAA6), although they were not all negative: "the evaluation I see it as suitable for my teacher since she uses observation a lot"(EPAA1).

Master's students, on the other hand, made criticisms that were less focused on aspects of the curriculum and more global, from a more ecological vision of the reality of the centers, such as the attention to diversity applied by some secondary school teachers and the lack of interest of families and resources: "I have also realized how lost teachers are in the attention to diversity, since most do not apply ordinary measures in the classroom and wait for the psychopedagogical evaluation; the low involvement of families, since in many cases learning or behavior difficulties could be overcome if they became more involved; as well as how difficult, if not impossible, it is to include children with serious disorders, such as ASD or serious conduct disorders, with the scarce resources available to the centers"'(MPAA5).

Finally, all reflected on their teaching role and their inclusive vision of education: "Our work as teachers is that, in the face of these circumstances of inequalities and the diverse contexts that we find ourselves in, help everyone to move towards the same leadership, leaving no one behind and serving as an example when they need it most "(EPAA9); "I have realized that the counselor's job requires a lot of paperwork and on many occasions it is complicated" (MPAA5); "The great difficulties that I have encountered have been the large number of students, a lot of administrative management and a lot of demand from tutors and families to carry out psycho-pedagogical evaluations, which are not really the solution, since important is the educational response "(MPAA5); "It is essential to deal with the emotions with the students since they influence the whole learning process. Personally, I consider it even more relevant that as teachers we also have the ability to manage our own emotions since it is the basis for emotional learning in our students to be meaningful and, above all, positive for the different situations they may have place in their lives" (MNAA2). 
Category 4-Supports:

Regarding the support category, the quantitative data that showed fewer comments among undergraduate students than among Master's students were confirmed; in fact, of the 21 comments collected in the first group, none of them showed support for their classmates, but rather they answered questions posed by the teachers.

On the other hand, Master's students understood the meaning of the forum as a group of self-help, joint reflection, and request and receipt of support throughout the internship period: "I think I have answered all your contributions, that, by the way they have seemed very interesting to me and have led me to reflect on various aspects, which, ultimately, is the main objective of this dynamic" (MNAA1). They continuously gave feedback among themselves that invited participation: "I find everything you comment very interesting" (MPAA4); "I hope you are enjoying and taking advantage of these practices." (MP21AA1), "I hope you have a good experience, you will tell us!" (MPAA5), "OMG XXX I love everything you are doing and learning!" (MP21AA2)," How nice! Congratulations, what a joy to read your experience" (MP21AA5).

In addition, they used exclamations and emoticons, as well as words in capital letters or of different type and color to express their emotions and the empathy that was established between them. We found phrases of encouragement that also showed empathy: "As you say, I think everything is getting used to. Courage" (MPAA4); "I felt the same as you knowing and learning a lot of content in a very short time. I have always thought that through experience is when you really learn. So... take advantage of this great opportunity!" (MP21AA2).

They commented on the work of their colleagues and reinforced their actions during the practices: "What an enriching and rewarding activity. I love that you spend time talking and talking about issues of interest to the students" (MNAA1); "What a good intervention! I totally agree with the reflection you share in the last paragraph" (MNAA2); "Well, I would have felt the same as you. Joining an unknown environment is complicated, and if the association's own staff does not integrate you or inform you beforehand, it causes a bad feeling. Even so, I am sure that your insecurity right now will change because with observation you learn a lot. In addition, it is a point in your favor that you are not the only student in practice. Maybe you could propose an activity together with some of your colleagues in practice and propose it to them, maybe they like the idea! Little by little, do not get discouraged, it will surely improve the situation, and you learn from everything, from the bad too! A kiss XXX. Go for it!!" (MNAA4).

Category 5-Doubts and Answers:

Finally, in this category, Table 5 is presented with some examples of the doubts and answers, together with their motivation or their type.

All citations correspond to Master's students, entries that begin with MN are from ENADS and those that begin with MP are from psychopedagogy.

As can be seen, Master's students used the fora in a collaborative way. They were able to use it as a meeting point for all, as a means of sharing experiences and learning from others. Undergraduate students only used it as an exhibitor of their work in the practices.

Table 5. Type of participation in fora by degree.

\begin{tabular}{|c|c|c|}
\hline Type & Doubts & Answers \\
\hline Advice & $\begin{array}{l}\text { I have seen that you have } \\
\text { passed several tests to students. } \\
\text { I will take a test shortly and I } \\
\text { have never done it before, could } \\
\text { you tell me how your } \\
\text { experience was or give me some } \\
\text { advice? (MPAA4). }\end{array}$ & $\begin{array}{l}\text { I did not know about these tests and my } \\
\text { tutor explained them to me briefly. The } \\
\text { truth is that when I passed them I was } \\
\text { nervous and tense at the same time, since I } \\
\text { was evaluating a child and they realize that } \\
\text { they are doing a kind of test, but I tried to } \\
\text { make it as enjoyable and "fun" as possible. } \\
\text { I was cheering and telling him that he was } \\
\text { doing great. (MPAA5). }\end{array}$ \\
\hline
\end{tabular}


Table 5. Cont.

\begin{tabular}{|c|c|c|}
\hline Type & Doubts & Answers \\
\hline Curiosity & $\begin{array}{l}\text { I only have one doubt, that you } \\
\text { have mentioned it at some point, } \\
\text { with children of what age range } \\
\text { do you work? (MP21AA2). }\end{array}$ & $\begin{array}{l}\text { Right now, we have children between the } \\
\text { ages of } 2 \text { and } 14 \text {. However, really, and } \\
\text { except for these moments, the CAIT is for } \\
\text { children from 0-6 years old and "Ongoing } \\
\text { Service" for over } 6 \text { years old. } \\
\text { I hope to clarify your doubt, } \\
\text { greetings (MP21AA1). }\end{array}$ \\
\hline Relationship & $\begin{array}{l}\text { After reading your post, I have } \\
\text { related the individual Early } \\
\text { Care plans with what I have } \\
\text { done in my internship. In this } \\
\text { case, they are not from Early } \\
\text { Childhood Care since most of } \\
\text { the students are teenagers ... . } \\
\text { My question is, would it be the } \\
\text { same? Is this considered an } \\
\text { individualized action plan? } \\
\text { Alternatively, am I missing } \\
\text { aspects to include in } \\
\text { it? (MP21AA2). }\end{array}$ & $\begin{array}{l}\text { I am attaching the document, although } \\
\text { with the data covered by data protection } \\
\text { and not with much quality, but the name } \\
\text { does look good. In addition, I think that we } \\
\text { do perform the same task. } \\
\text { Thank you very much for your } \\
\text { contribution, kisses. (MP21AA1). }\end{array}$ \\
\hline Beliefs & $\begin{array}{l}\text { We think that the emotional } \\
\text { dimension is very important in } \\
\text { the students' learning processes } \\
\text { and in their well-being in } \\
\text { general, therefore, we consider } \\
\text { that it should have more place } \\
\text { in the educational context. Do } \\
\text { you think like us? (MNAO3) }\end{array}$ & $\begin{array}{l}\text { I totally agree with the reflection ... It is } \\
\text { essential to deal with emotions with } \\
\text { students since they influence the entire } \\
\text { learning process ....., I consider even more } \\
\text { relevant that as teachers we also have the } \\
\text { ability to manage our own } \\
\text { emotions (MNAA2) }\end{array}$ \\
\hline $\begin{array}{l}\text { Consultation } \\
\text { prior planning }\end{array}$ & $\begin{array}{l}\text { I have thought of offering } \\
\text { innovative resources and } \\
\text { strategies that promote the } \\
\text { objectives that the monitor has } \\
\text { for the user while discovering } \\
\text { how to intervene in a } \\
\text { meaningful and positive way. } \\
\text { What do you guys think? Do } \\
\text { you have the same feeling as } \\
\text { me? I appreciate all kinds of } \\
\text { advice! (MNAA2). }\end{array}$ & $\begin{array}{l}\text { I think the same, that you can offer } \\
\text { resources and innovative strategies so that } \\
\text { you as "practice monitors" can do new } \\
\text { things (within the possibilities that the } \\
\text { company leaves you), and if you can put it } \\
\text { into practice much better You are already } \\
\text { telling us (MNAO3). }\end{array}$ \\
\hline
\end{tabular}

Source: made by the authors.

\subsection{Student Assessment of the Methodology Followed}

The last objective (O4) was to know the students' assessment of the follow-up of the practices with this methodology, and in all cases we found that the students made positive assessments, regardless of the degree and whether explicitly asked about the valuation of the methodology or not. However, the positive aspects were different.

Undergraduate students affirmed that the elaboration of the report in a leisurely way facilitated their daily work, gave them security, and was more comfortable than doing all the work at the end: "this way of carrying out the memory is very attractive to me and dynamic, I try to keep everything up to date and thus not accumulate all the work for the end. Teacher-student feedback is the most important thing to know that we are on the right track. In general, I am very satisfied with all this experience" (EPAA6); "I think the model of commenting on what we are doing every day is great, it is also easy to use and comfortable" (EPAA3); "Personally, I am liking this way of working, since, in my case, I keep a diary in which I write down my day-to-day life and especially the really important 
things that I know will serve me in my future as a teacher. I feel that I do not have the pressure of having to write "mandatory" and daily about everything that happens and I carry it with less stress, because of this, I am enjoying the practices more. Regarding a topic per week, it seems great to me and we are also gradually making the memory that so much uncertainty generated me (EPAA5).

Master's students observed other benefits such as knowing the work of their classmates in other contexts, sharing experiences, and motivating themselves: " ... it has had a very good methodology, because I have not only had my internships that I have lived in the first person, but also that of my colleagues who have been told every week the most relevant of their practices and with this I have also learned a lot. Thank you for that forum, and with it the new lessons and learnings "(MP21AA1); "I have never held a forum in this way before, but it has been very interesting and beneficial for our practice and thus to be able to share our experience and be able to know the experience of others (MP21AA5); "In addition to having learned from everything we have shared, I have been getting to know what the experience of my classmates was like and although it was indirectly, I have learned a little more about the work of a counselor within an institute" (MP21AA2); "If it weren't for the blog, I probably wouldn't have known how interesting it is to work as a psychopedagogue outside of a school" (MP21AA4); "When XXX told us in the first meeting that we would use a blog to share our experiences, I did not imagine that the result would be as positive as it is turning out to be. Being able to read your ideas and experiences, somehow allow me to imagine myself there with you and reflect on how I would feel or act in each of the contexts and/or situations you describe" (MNAA2); "I am looking forward to you sharing experiences again, I read you carefully. A very strong kiss!" (MNAA1).

They also highlighted its importance in clarifying doubts, overcoming difficulties, and increasing learning: "regarding the difficulties I have had, many have had to do with the fact that I felt insecure when starting to work with adolescent students or with lack of experience. Of them, we have been solving most of them through the forum. Therefore, I take the opportunity to say that I value the forum very positively" (MP21AA2); "I want to emphasize the forums, an extra learning that our group has had thanks to this methodology" (MP21AA3); and finally, we collected an expression that we found interesting because it summarized the level of importance that the forum assumed: "Thank you for your contributions. In addition, you are right, the blog hooks! Hahahaha" (MNAA2).

Finally, to complete this objective, it should be noted that when students were asked about the proposals for improving the practices, none of them made proposals about the follow-up of the practices or the methodology followed. Only the students of the Master's in psychopedagogy of the 2020-2021 academic year indicated proposals, but referred to the organization of the practices within the training period, advocating that these be carried out at the end of the training period and not in the middle of it: "Something that would change is the time of the internship, I think it would have been even more enriching after having taken all the subjects" (MP21AA1); "I do consider that the practices could be done at the end of the course because we have the specialty and I think that we could give more of ourselves (MP21AA2); "I think that one aspect that could be improved with respect to the internship period is undoubtedly the duration. I understand that it is a short, one-year and consequently intensive Master's degree, but personally I would have preferred to start after the first term, another term with the new subjects and leave the internship as a final experience, when the learning background is certainly broader and more solid. This is the only suggestion that comes up and that I think could be improved" (MP21AA3). There was also a proposal referring to their timing: "As it is a very intense year, I would distribute those hours over more weeks, even if we only had to go two days a week. So we could see evolutions in the students, see different stages, and more learning" (MP21AA3). In all cases they were justified by training reasons and interest in improving the development of practices. 


\section{Discussion}

The results regarding the level of participation in the fora showed a difference in the number and type of publications. This difference was independent of the duration of the practices ( 30 credits, $300 \mathrm{~h}$ in primary and 6 credits, $60 \mathrm{~h}$ in the Master's). The average number of posts per student also differed, so that, over time, they made fewer posts. This could be explained because, since they were students with fewer years of training, they spent more time preparing the activities proposed in the practice centers, investing less time in the forums. It could also be due to the greater number of students in the forum, which further dissipates the individual responsibility to include content in it; or even because inexperience made them grasp fewer important nuances to highlight in their internship period.

Regarding the type of participation, Master's students carried out more interactions with each other than undergraduate students, who were limited to answering the teachers' questions.

On the other hand, the analysis of the fora showed great differences with respect to their content between undergraduate and Master's students. The fundamental differences focused on the detail of the descriptions given, the theoretical and personal reflections (from a critical point of view), the type of support they established between them, and the use of the fora to ask questions and give answers. However, they coincided in the expression of their initial feelings and in the causes of difficulties in them throughout the internship period. Furthermore, in both cases, the students showed an inclusive vision of their role as future teachers, fundamentally providing criticism when they observed that attention to diversity was not carried out in an adequate way.

The reasons that can explain this reality are various. On the one hand, the years of university training, which in the first students represented only three years, while the second received a more extensive university training, they carried out previous internships during two undergraduate courses. This was, at least, their third practical experience, which gave them greater knowledge and judgment to intervene, question, and maintain a fluid debate among their peers.

Another reason may be the number of students that make up the groups; while the Bachelor's group was made up of 10 students, the Master's students were only 4 or 5. Therefore, a greater climate of trust was created between them and facilitated their management by the faculty. In this sense, authors such as [37] also consider that one of the difficulties is related to administrative aspects, due to "the number of internships that the teaching staff must attend", which makes it difficult to monitor the students even at a distance. Consequently, it does not allow the maximum development of students. Therefore, our proposal advocates a maximum of six students per teacher. Finally, it is suggested that their levels of technological development differed because the TPACK Model was not sufficiently developed during its formation [38]. Another reason is the lack of transfer, although it has been learned [39].

In relation to the pedagogical aspects, or those related to the learning of the students in the sample, it was observed that they were able to identify theories and practice, although not with the desired intensity, in line with [40] that states that a connection between theory and practice was not achieved in teacher training. For this reason, it is vitally important to take advantage of the internship period to reflect on the theoretical content and its application in classrooms or practice centers. It was observed that this was the greatest difficulty for students and increased when there were fewer years of training received. Therefore, it would be necessary for the teachers who tutor practices to have a broad theoretical and practical knowledge about different study areas (didactic, organizational, methodological, social, and technological skills) to guarantee its tutorial function. In addition, knowledge of the reality of the centers would also be necessary, which would be favored through good communication with the tutors of the centers [41-43]. In fact, the professional tutors of the centers were also part of the fora [44], although we did not 
consider that the benefits were so favorable, since they would limit the freedom of the students to express critical reflections and difficulties experienced in some experiences.

Regarding the evaluation of the proposed innovation, the results coincided with those of $[45,46]$, who affirmed that the fora were highly valued by students in a positive way. Specifically, the evaluations of the Master's students were also in line with those made by psychopedagogy students from the University of Vigo [47], Granada [48], and Huelva [49], whose evaluations of the practices were good. Unlike these, and as a solution to one of the worst-valued aspects in the latest research, the advice and supervision of university teaching staff and the continuous feedback methodology through fora makes it possible to make up for this deficiency [50]. At an international level, these results coincided with [51] whose students increased the social and functional value of their practices when they received support from the teaching staff. There was also agreement with $[52,53]$, since the model used allowed critical self-reflection and the integration of different perspectives.

However, differences were observed in the assessment of the relationships between mentor teachers and students with the research carried out in Turkey [54]. These indicated high degrees of mistrust between the two. The students of this study, despite some disagreements, positively valued the support of the tutors of the centers where they carried out their internships.

The improvement proposals differed from those of the MAES students who proposed to extend the duration of the practices [55-57], although they also affected temporal aspects of the practices. However, in this aspect, they were in line with [58-62], since in both studies, the student proposed to extend the duration of the practices, indicating a greater learning during them.

\section{Conclusions and Limits}

The use of partition fora to monitor professional practices is an effective resource that allows users to:

1. Include questions referring to feelings, which serve to let students know that they can count on the tutor or professional tutor on a continuous basis, on addition to feeling supported in this formative stage, which represents for many students the first encounter with the reality of the centers and creates a certain insecurity for them. However, it was also observed that it occurred not only in undergraduate students, but also in Master's students, despite having previous experiences.

2. Present ambivalent situations, which they easily overcome, and express situations that are more negative for them. This can be channeled during the process so that they consider them as something normal and learn to understand them from another point of view.

3. Continuously evaluate, encourage, or provide proposals to develop the practices.

4. Facilitate knowledge of the techniques used by professionals from other centers and other colleagues, thus allowing learning to be generalized in different contexts, even if it is not that of each student. It can be said that they live practices in different realities in parallel.

5. Share resources or strategies to work crosscutting issues on emotional education, and even share proposals to solve problems that arise and ask for support, advice, or proposals to develop in the centers.

In conclusion, these advantages, with respect to the delivery of a final report, which was only read by the corresponding teacher, were undoubtedly one of the greatest contributions of this innovation. Students not only learned from what they personally experienced, but also enriched themselves with the learning of their peers and facilitated collaborative learning. In this sense, all shared their findings, resources, experiences, reflections, and the work they did in their respective centers.

On the other hand, it was possible to carry out the practice report and the diary progressively, avoiding a final rush and forgetting situations or learning; it facilitated reflective systematization, but without being constrained to a specific moment, since they 
had a full week to make their entries in the forum. The continuous evaluation was another advantage, since it allowed improving the documents elaborated when they were not yet delivered in a definitive way, as it happened before, and therefore it was formative. This platform allowed the user to include, in addition to texts, images and documents, so it was very useful for sharing any type of information with everyone.

Finally, regarding the students' assessment of the innovation carried out, only positive aspects were found. However, as a proposal for improvement, it would be necessary to expand the functionality of the forums, including not only training and development aspects, but also self-evaluation and co-evaluation of university students.

For this, it will be necessary to incorporate elements such as e-rubrics or e-portfolios (Moodle-Mahara) and video annotations (Open Video Annotation-OVA/CoAnnotation), among others $[18,33]$. Despite this, it is considered that the simple act of writing for classmates in a "public" way, not only in a private final evaluation document that will only be evaluated by the teacher, already produces a certain self-evaluation and improves the mode of communication and expression of students [63].

Another proposal for improvement would be to carry out prior training for the collaborative use of the forum for undergraduate students. It should be taken into account that the students experienced the forum as a univocal relationship with the teaching staff, forgetting its meaning to facilitate joint reflection. They completed all the proposed entries but paying more attention to an evaluative character and the progressive elaboration of their memory of practices. In other words, they had a more individualistic way of working. In contrast, the Master's students, reduced the number of entries and increased the comments, identifying the formative nature of the blog for joint reflection. They, too, lived it as a continuous support group where advice, encouragement, and all kinds of questions were raised. They wanted to tell in all their entries how they lived their practices, exposing them to the opinion of others, trying to contribute to the increase of group knowledge, such that their wealth and learning was superior.

In the same sense, it is necessary to specify to undergraduate students that the blog is an instrument of interaction with their own classmates and not only with the teaching staff. This was reflected in the discourse analysis because they used indirect language, as if they did not know the people with whom they shared the forum. However, Master's students used direct language with their classmates with phrases such as "Hello guys!!" or "Dear colleagues!!"; they were aware that their writings were directed to specific people, they made the fora their own and they hardly required the intervention of teachers to create threads of conversations. To facilitate the use of the blog, a video material or brief information pill could be prepared where the students who participated explain its use and advantages to other students in subsequent courses. Their viewing could also be included in the first meeting with the students.

In the same way, although different experiences were described for the follow-up of the practices throughout the article, there is no single criterion, nor is there a consensual model among all the professionals or departments of our faculty; its development depends in a certain way on the criteria of the teaching staff or groups of teachers who started this work out of personal interest and conviction, or under teaching innovation projects. Like other authors who affirm that its implementation is not generalized, at the state level, it is considered that it would be necessary to implement these innovations in a more generalized way in light of the results of these investigations that refer to a substantial improvement for the competency learning of students of any educational level [54-56].

Finally, as a specific limitation of the research carried out, reference is made to the proportion of the sample. Although it was heterogeneous with respect to the degrees of origin, it was small in number. This means that the findings and conclusions made throughout the article cannot be generalized to other contexts without first expanding the sample. For this reason, it is necessary to extend it for future research, even in other faculties of education to see if the results are consistent. However, the model described, the 
categories of analysis, and the different results can guide the conduction of new research in this line, offering conclusions to prevent the difficulties encountered.

Author Contributions: Conceptualization, C.C.-V. and R.B.-S.; methodology, C.C.-V.; software, A.P.R.; validation, A.P.-R.; writing—original draft preparation, C.C.-V.; writing—review and editing, C.H.G.; visualization, C.H.-G.; supervision, R.B.-S.; project administration, R.B.-S.; funding acquisition, R.B.-S. All authors have read and agreed to the published version of the manuscript.

Funding: This research was funded by Faculty of Educational Sciences, University of Seville, grant number "Call 2019-20", project "Security in virtual space: environmental impact, cyberbullying and technological addiction. Training for teachers and educators through the flipped classroom method".

Conflicts of Interest: The authors declare no conflict of interest.

\section{References}

1. González-Valiente, C.L. Tendencias Emergentes Sobre el Tópico Tecnologías de Información en el Campo de las Ciencias de la Educación: Una Exploración Bibliométrica. Educ. Knowl. Soc. 2015, 16, 91. [CrossRef]

2. Díaz, M.D. Supervisión y evaluación del prácticum de pedagogía mediante el uso de la Web 2.0. In Evaluación y Supervisión del Prácticum: El Compromiso con la Calidad de las Prácticas; Raposo-Rivas, E.M., Martínez-Figueira, M.E., Muñoz, P.C., Otero, A.P.Y.J.C., Eds.; Andavira: Santiago de Compostela, Spain, 2011; pp. 641-647.

3. Zabalza, J.M. El Practicum y las Prácticas Externas en la Formación Universitaria. Rev. Pract. 2016, 1, 1-23.

4. Amorós-Poveda, L. Competencia Digital Docente en Prácticum Desde la Autoevaluación. Rev. Pract. 2020, 5, 30-46.

5. Fernández-Muñoz, R.; Gértrudix-Bariio, F.; Cisneros de Britto, J.C.; de Rodríguez-Torres, J.; Rivas Rebaque, B. La Formación del Profesorado en Tecnología Educativa: Prácticas Profesionales. Rev. Latinoam. Tecnol. Educ. 2015, 14, 115-132. [CrossRef]

6. Fernández, R. Las tecnologías de la información y la comunicación aplicadas al prácticum de los futuros educadores en la universidad de castilla-la mancha. In El Prácticum Como Experiencia de Aprendizaje en Educación Social: Propuestas Para su Desarrollo: Planificación, Tutoría Docente y Proyección Social; Morales, E.S., Ed.; Universitas: Madrid, Spain, 2013; pp. 117-148.

7. Raposo-Rivas, M. Herramientas y recursos para el desarrollo del prácticum. In El Prácticum en Educación Infantil, Primaria y Máster de Secundaria; Ramírez, E.S., Sánchez, C., Latorre, A.G.Y.M.J., Eds.; EOS: Madrid, Spain, 2011; pp. 31-50.

8. Mayorga Fernández, M.J.; Sepúlveda Ruiz, M.P.; Madrid Vivar, D.; Gallardo Gil, M. Grado de Satisfacción y Utilidad Profesional de las Prácticas Externas del Alumnado de la Facultad de Ciencias de la Educación de la Universidad de Málaga (España). Perf. Educ. 2017, 39, 140-159. [CrossRef]

9. Ballesteros-Regana, C.; Siles-Rojas, C.; Hervás-Gómez, C.; Diaz-Noguera, M.D. Improving the Quality of Teaching Internships with the Help of the Platforms. Eur. J. Educ. Res. 2019, 8, 1101-1112. [CrossRef]

10. Pintrich, P.R. The Role of Motivation in Promoting and Sustaining Self-Regulated Learning. Int. J. Educ. Res. 1999, 31, 459-470. [CrossRef]

11. Waugh, M.; Su-Searle, J. Successful online students' perceptions of the value of a collaborative learning community. In Proceedings of the 35th Annual Meeting of the Association for Educational Communications and Technology, Louisville, KY, USA, 2-6 November 2012; pp. 416-424.

12. Darling-Hammond, L.; Adamson, F. Developing Assessments of Deeper Learning: The Costs and Benefits of Using Tests That Help Students Learn; Stanford University, Stanford Center for Opportunity Policy in Education: Stanford, CA, USA, 2013.

13. Riaño-Galán, A.; García-Ruíz, R.; Álvarez-Arregui, E. Calidad de Vida e Inserción Socio-Laboral de Jóvenes con Discapacidad. Electron. J. Educ. Res. Rev. Electron. Investig. Educ. 2016, 18, 112-127.

14. De Wever, B.; Hämäläinen, R.; Voet, M.; Gielen, M. A Wiki Task for First-Year University Students: The Effect of Scripting Students' Collaboration. Internet High. Educ. 2014, 25, 37-44. [CrossRef]

15. Fischer, F.; Kollar, I.; Stegmann, K.; Wecker, C.; Fischer, F.; Kollar, I.; Stegmann, K.; Wecker, C. Toward a Script Theory of Guidance in Computer-Supported Collaborative Learning toward a Script Theory of Guidance in Computer-Supported Collaborative Learning. Educ. Psychol. 2013, 48, 56-66. [CrossRef] [PubMed]

16. Rau, M.A.; Bowman, H.E.; Moore, J.W. Computers \& Education an Adaptive Collaboration Script for Learning with Multiple Visual Representations in Chemistry. Comput. Educ. 2017, 109, 38-55. [CrossRef]

17. Vogel, F.; Wecker, C.; Kollar, I. Socio-Cognitive Scaffolding with Computer-Supported Collaboration Scripts: A Meta-Analysis. Educ. Psychol. Rev. 2017, 29, 477-511. [CrossRef]

18. Manwaring, K.C.; Larsen, R.; Graham, C.R.; Henrie, C.R.; Halverson, L.R. Investigating Student Engagement in Blended Learning Settings Using Experience Sampling and Structural Equation Modeling. Internet High. Educ. 2017, 35, 21-33. [CrossRef]

19. Nilsson, P. From Lesson Plan to New Comprehension: Exploring Student Teachers' Pedagogical Reasoning in Learning about Teaching. Eur. J. Teach. Educ. 2009, 32, 239-258. [CrossRef]

20. Lin, P.C.; Hou, H.T.; Wang, S.M.; Chang, K.E. Analyzing Knowledge Dimensions and Cognitive Process of a Project-Based Online Discussion Instructional Activity Using Facebook in an Adult and Continuing Education Course. Comput. Educ. 2013, 60, 110-121. [CrossRef] 
21. Aneas, A.; Rubio, M.J.; Vilà, R. Digital Portfolios and Assessment of Transversal Competencies in Internships of the Bachelor's Degree in Pedagogy at the University of Barcelona. Educar 2018, 54, 283-301. [CrossRef]

22. Khalil, S. Improving Practice Teaching in Primary Schools for School Internship Programme. Voices Teach. Teach. Educ. 2020, 9, 72-84.

23. Gallego Arrufat, M.; Gámiz Sánchez, V.; Pérez García, M.; Romero López, M. Desarrollo de Competencias en el Prácticum con Materiales y Actividades Online. Píxel Bit. Rev. Medios Educ. 2009, 34, 135-150. [CrossRef]

24. Cebrián de la Serna, M. Supervisión con E-Portafolios y Su Impacto en las Reflexiones de los Estudiantes en el Practicum. Estudio de Caso. Rev. Educ. 2011, 354, 183-208.

25. Esqué Boldú, S.; Gisbert Cervera, M.; Larraz Rada, V. El Uso del E-Portafolios en las Prácticas del Bàtxelor en Enfermería. REDU Rev. Docencia Univ. 2014, 12, 399-423. [CrossRef]

26. Palomares, A. El portafolios como metodología activa en el diseño y desarrollo del prácticum. In Proceedings of the IX Symposium Internacional Sobre Practicum y Prácticas en Empresas en la Formación Universitaria, Universidad de Vigo, Poio (Pontevedra), Spain, 27-29 June 2007.

27. Colomo Magaña, E.; Gabarda Méndez, V.; Cívico Ariza, A.; Cuevas Monzonís, N. Percepción de estudiantes sobre el uso del videoblog como recurso digital en educación superior. Píxel Bit. Rev. Medios Educ. 2020, 59, 7-25. [CrossRef]

28. Rodríguez-Gallego, M.R.; Ordóñez-Sierra, R. Metodologías Activas Desarrolladas en la Supervisión de las Prácticas Externas del Grado en Pedagogía. Rev. d'Innov. Docent Univ. 2021, 13, 1-8.

29. Ríos, M.; Moreno, M.L.; Sánchez, M.C.; Gómez del Castillo, M.T. Tutoría, supervisión y evaluación del prácticum en educación. In El Perfil Profesional del Pedagogo: Experiencias Desde una Visión Práctica; Gutiérrez, E.J.J., Ordóñez, Y.R., Eds.; Universidad de Sevilla, Grupo GID: Sevilla, Spain, 2011.

30. Barrón, C. Concepciones Epistemológicas y Práctica Docente: Una Revisión. REDU Rev. Docencia Univ. 2015, 13, 3. [CrossRef]

31. García-Cabrero, B.; Loredo, J.; Carranza, G. Análisis de la Práctica Educativa de los Docentes: Pensamiento, Interacción y Reflexión. REDIE Rev. Electrón. Investig. Educ. 2008, 10, 1-10.

32. Martínez-Rizo, F. Procedimientos Para el Estudio Sobre las Prácticas Docentes: Revisión de la Literatura. Relieve Rev. Electrón. Investig. Eval. Educ. 2012, 18, 1-22.

33. Del Montes, L.C.; Caballero, T.P.; Miranda, M.L. Análisis de las Prácticas Docentes: Estado del Conocimiento en DOAJ y EBSCO. Rev. Investig. Educ. 2017, 25, 198-229.

34. Jackson, P.W. La Vida en las Aulas; Morata, S.A., Ed.; SlideShare: Madrid, Spain, 2009.

35. Cid Sabucedo, A.; Pérez Abellás, A.; Zabalza Beraza, M.A. Las Prácticas de Enseñanza Realizadas/Observadas de los Mejores Profesores de la Universidad de Vigo. Educ. XX1 2013, 16, 265-296. [CrossRef]

36. Fleiss, J.L.; Cohen, J.; Everitt, B.S. Large Sample Satandard Errors of Kappa and Wighted Kappa. Psychol. Bull. 1969, $72,323-327$. [CrossRef]

37. Gelfand, D.M.; Hartmann, D.P. Child Behavior Analysis and Therapy; New York Press: New York, NY, USA, 1975.

38. Gallego-Arrufat, M.J.; Cebrián de la Serna, M. Contribuciones de las Tecnologías Para la Evaluación Formativa en el Prácticum. Profr. Rev. Curríc. Form. Profr. 2018, 22, 139-161. [CrossRef]

39. Zeichner, K. Nuevas Epistemologías en Formación del Profesorado: Repensando las Conexiones Entre las Asignaturas del Campus y las Experiencias de Prácticas en la Formación del Profesorado en la Universidad. Rev. Interuniv. Form. Profr. 2010, 24, 123-149.

40. Kivunja, C. Embedding Digital Pedagogy in Pre-Service Higher Education to Better Prepare Teachers for the Digital Generation. Int. J. High. Educ. 2013, 2, 131-142. [CrossRef]

41. Hu, X.; Yelland, N. An Investigation of Preservice Early Childhood Teachers' Adoption of ICT in a Teaching Practicum Context in Hong Kong. J. Early Child. Teach. Educ. 2017, 38, 259-274. [CrossRef]

42. Ong'ondo, C.O.; Jwan, J.O. Research on Student Teacher Learning, Collaboration and Supervision during the Practicum: A Literature Review. Educ. Res. Rev. 2009, 4, 515-524. [CrossRef]

43. Martínez, E.; Raposo, M. Funciones Generales de la Tutoría en el Practicum: Entre la Realidad y el Deseo en el Desempeño de la Acción Tutorial. Rev. Educ. 2011, 354, 155-181.

44. Zeichner, K. Rethinking the Connections between Campus Courses and Field Experiences in College and Universi-Ty-Based Teacher Education. Educaçao 2010, 3, 479-501.

45. Raposo-Rivas, M.; Martínez-Figueira, M.E. ¿Tecnologías Emergentes o Tecnologías Emergiendo? Un Estudio Contextualizado en la Práctica Preprofesional. Educar 2019, 55, 1-20.

46. Gallego-Arrufat, M.J.; Gámiz-Sánchez, V. Un Camino Hacia la Innovación Basada en un Entorno de Aprendizaje Virtual Aplicado a la Inmersión Práctica en los Estudios Universitarios de Educación. Rev. Latinoam. Tecnol. Educ. 2007, 6, 13-32.

47. On, C.; Attitude, S. Virtual Learning Environments in Faculties of Education in Spain: Changes on Student Attitude. J. Educ. Teach. Train. 2010, 1, 42-50.

48. Cid Sabucedo, A.; Ocampo Gómez, C.I. Funciones Tutoriales en el Prácticum de Psicopedagogía en La Universidad de Vigo: Percepciones de los Estudiantes Actuales. Rev. Educ. 2007, 344, 285-307.

49. Sánchez, C.A.; García, A.; Fernández, S.R. La mejora del prácticum a través de la implicación y reflexión de sus agentes: Reflejos de un proceso de investigación-acción. In El Practicum en Educación Infantil: Primaria y Máster de Secundaria; Ramírez, S., Sánchez, C.A., García, A., Latorre, M.J., Eds.; EOS: Madrid, Spain, 2011; pp. 241-278. 
50. Tello Díaz, J. Implicaciones Formativas Del Prácticum de Psicopedagogía En Los Centros de Educación Secundaria. Profr. Rev. Curríc. Form. Profr. 2007, 11, 1-16.

51. Gil-Molina, P.; Ibáñez-Etxeberria, A.; Arribas, S.; Jaureguizar, J. El Practicum del Máster de Formación del Profesorado de Secundaria: Valoraciones del Alumnado y del Profesorado-Tutor. Profr. Rev. Curríc. Form. Profr. 2018, 22, 1-17. [CrossRef]

52. To, W.M.; Lung, J.W.Y. Factors Influencing Internship Satisfaction among Chinese Students. Educ. Train. 2020, 62, 543-558. [CrossRef]

53. Zhu, G.; Membiela, P.; Wang, K. Examining Chinese and Spanish preservice teachers' practicum teaching experiences: A transformative learning perspective. J. Educ. Teach. 2020, 46, 124-128. [CrossRef]

54. Craig, C.J.; Zou, Y.; Poimbeauf, R. Journal Writing as a Way to Know Culture: Insights from a Travel Study Abroad Program. Teach. Teach. 2015, 21, 472-489. [CrossRef]

55. Baştürk, S. Examining Primary Pre-service Teachers 'perspectives on teaching practice courses. Acta Didact. Napoc. 2016, 9, 35-46.

56. Bartolomé-Pina, A.; Gallego-Arrufat, M.J.; Pérez-Galán, R.; Sarmiento-Campos, J.A.; Baelo-Álvarez, R.; Páramo-Iglesias, M.B.; García-Beltrán, A.; Tapia-Fernández, S. Los modelos de uso de las tecnologías para la evaluación de los aprendizajes en el prácticum en las facultades de ciencias de la educación en españa: Encuestando a los gestores. In Documentar y Evaluar la Experiencia de los Estudiantes en las Prácticas; Raposo-Rivas, M., Muñoz Carril, P.C., Zabalza-Cerdeiriña, M., Martínez-Figueira, M.E., Pérez-Abellás, A., Eds.; Andavira: Santiago de Compostela, Poio, Spain, 2015.

57. Filiz, B.; Durnali, M. The views of pre-service teachers at an internship high school on pedagogical formation program in Turkey. Eur. J. Educ. Res. 2019, 8, 395-407. [CrossRef]

58. Barragán-Sánchez, R.; Corujo-Vélez, M.C.; Palacios-Rodríguez, A.; Román-Graván, P. Teaching Digital Competence and EcoResponsible Use of Technologies: Development and Validation of a Scale. Sustainability 2020, 12, 7721. [CrossRef]

59. Cabero-Almenara, J.; Barroso-Osuna, J.; Gutiérrez-Castillo, J.-J.; Palacios-Rodríguez, A. The Teaching Digital Competence of Health Sciences Teachers. A Study at Andalusian Universities (Spain). Int. J. Environ. Res. Public Health 2021, 18, 2552. [CrossRef]

60. Romero-Tena, R.; Llorente-Cejudo, C.; Puig-Gutiérrez, M.; Barragán-Sánchez, R. The Pandemic and Changes in the Self-Perception of Teacher Digital Competences of Infant Grade Students: A Cross Sectional Study. Int. J. Environ. Res. Public Health 2021, 18, 4756. [CrossRef] [PubMed]

61. Infante-Moro, A.; Infante-Moro, J.; Gallardo-Pérez, J. The acquisition of ICT skills at the university level: The case of the Faculty of Business Studies and Tourism of the University of Huelva. Píxel Bit. Rev. Medios Educ. 2021, 60, 29-58. [CrossRef]

62. Ordóñez-Olmedo, E.; Vázquez-Cano, E.; Arias-Sánchez, S.; López-Meneses, E. Las Competencias en el uso de las Tecnologías de la Información y la Comunicación en el alumnado universitario. Píxel Bit. Rev. Medios Educ. 2021, 60, 153-167. [CrossRef]

63. Sepúlveda-Ruiz, M.P.; Guillén-Gámez, F.D.; García-Vila, E.; Mayorga-Fernández, M.J. Emotional competence of prospective early childhood and primary education teachers: Analyses of significant predictors. Form. Univ. 2021, 14, 105-114. [CrossRef] 